\title{
PERMASALAHAN PENDIDIKAN DI ERA PANDEMI
}

\author{
Endang Astuti \\ Email: 2010128220009@ulm.ac.id \\ Program Studi Pendidikan IPS Fakultas Keguruan dan Ilmu Pendidikan \\ Universitas Lambung Mangkurat \\ Banjarmasin
}

\begin{abstract}
Abstrak
Pendidikan merupakan selaku usaha sadar serta terencana untuk mewujudkan atmosfer belajar serta proses pendidikan untuk partisipan didik secara aktif meningkatkan kemampuan dirinya buat mempunyai kekuatan spiritual keagamaan, pengendalian diri, karakter, kecerdasan, akhlak mulia, dan keahlian yang dibutuhkan dirinya serta warga.
\end{abstract}

\section{PENDAHULUAN}

Pendidikan merupakan selaku usaha sadar serta terencana buat mewujudkan atmosfer belajar serta proses pendidikan untuk partisipan didik secara aktif meningkatkan kemampuan dirinya buat mempunyai kekuatan spiritual keagamaan, pengendalian diri, karakter, kecerdasan, akhlak mulia, dan keahlian yang dibutuhkan dirinya serta warga. Penafsiran Pembelajaran bisa dimaksud selaku usaha sadar serta sistematis untuk menggapai taraf hidup atau buat kemajuan lebih baik. Secara simpel, Penafsiran pembelajaran merupakan proses pendidikan untuk partisipan didik buat bisa paham, mengerti, serta membuat manusia lebih kritis dalam berpikir. penafsiran pembelajaran, Pembelajaran bisa diperoleh baik secara resmi serta non resmi. Pembelajaran secara resmi diperoleh dengan menjajaki program- program yang sudah direncanakan, terstruktur oleh sesuatu insititusi, kementerian ataupun kementtrian sesuatu negeri semacam di sekolah pembelajaran membutuhkan suatu Kurikulum buat melakukan perencanaan penganjaran. Sebaliknya pembelajaran non resmi merupakan pengetahuan yang diperoleh dari kehidupan tiap hari dari bermacam pengalaman baik yang dirasakan ataupun dipelajari dari orang lain. 


\section{PANDEMI DALAM PENDIDIKAN}

Pandemi COVID-19 telah mengubah berbagai aspek kehidupan manusia saat ini, terutama di bidang pendidikan. Ini menuntut semua elemen pendidikan untuk beradaptasi dan melanjutkan sisa semester. Di masa pandemi covid dikala ini, Pembelajaran di Indonesia ialah salah satu yang terserang akibat sangat besar. Semenjak pertengahan Maret 2020, Indonesia tingkatkan status bahaya Pandemi, sehingga seluruh wajib melaksanakan pembatasan yang diucap selaku Lockdown sepanjang kurang lebih 2 minggu lamanya, akibat Virus Corona, ataupun diketahui dengan istilah Covid 19. Pembatasan yang dicoba sepanjang 2 minggu diharapkan dapat kurangi efek tingkatan persebaran virus covid 19, namun nyatanya perihal ini tidak berjalan semacam yang direncanakan. Persebaran covid terus menjadi besar sehingga Sekolah yang awal mulanya diliburkan sepanjang 2 minggu, hadapi pergantian ialah Work from Home sepanjang waktu yang belum dapat di tentukan. Perihal ini menyebabkan segala sekolah di Indonesia, mulai dari jenjang Halaman Anak- anak hingga Universitas meliburkan partisipan didik nya, sebab di khawatirkan kalau tingkatan kerumunan yang besar, dapat jadi Cluster baru pada persebaran covid 19.

\section{TRANSFORMASI BELAJAR DALAM KAJIAN TEORITIS PRAKTIS}

\section{A. PERUBAHAN / TRANSFORMASI CARA BELAJAR SELAMA PANDEMIC COVID -19}

Pergantian ataupun tranformasi metode belajar sepanjang pandemi covid- 19 berbeda dengan metode belajar saat sebelum pandemi, saat sebelum terdapatnya covid tersebut metode belajar anak murid secara tatap muka serta pembelaajaran di laksanakan di dalam kelas serta saat ini sehabis terdapatnya pandemi covid ini metode belajar juga berganti, sistem belajar pada pandemi ini lewat secara online/ secara daring yang mana metode ini lah yang dapatt di jalani supaya sesuatu pendidikan bisa terus di jalankan, ada pula terdapatnya akibat positif dari terdapatnya sistem belajar secara daring ialah yang awal yakni cepatnya tranformaasi di dalam

pembelajaran yang mana tranformasi ini supaya bisa berjalannya pendidikan sepanjang masa covid ini, yang kedua yakni banyak nya sesuatu kemunculan aplikasi belajar serta pula kursus online sebab aplikasi belajar sangat berarti untuk para perserta didik buat melanjutkan sutu jalnnya pendidikan supaya tidak terfokus dengan terdapatnya perbandingan dalam sistem belajar, 
yang ketiga yakni tumbuhnya kreativitas serta mental positif yang mana situasi pandemi ini banyak orang-orang yang menciptakan sebuah kesempatan baru melalui kreatifitas agar tetap bisa bertahan didalam masa pandemi ini.

\section{B. BENTUK RELEVASI TEORI BELAJAR DALAM KEBUTUHAN PEMBELAJARAN DARING PADA MASA PANDEMI}

Teori belajar behaviorisme merupakan suatu perubahan mental yang terdapat di dalam individu setelah melakukan belajar, yang mana faktor-faktor terebut tidak di perhatikan dan juga dianggap sebagai sebuah hasil belajar karena telah dianggap sebagai hal yang tidak dapat diamati dan juga tidak dapat di ukur, dan juga teori belajar ini selalu menyyerderhanakan sesuatu hal yang mana berkaitan dengan pendidikan dan atau belajar sekedar pada suatu hubungan stimmulus dan respon saja yang mana juga serta mampu menjelaskan penyimpangan yang terjadi dalam suatu hubungan stimulus dan respon itu sendiri dan teori belajar ini di perluka dalam suatu pembelajaran apalagi di saat masa pandemi ini dimana pada saat ini pembelajaran dilakukan secara online atau bisa di sebut dengan daring, pembentukan relevasi belajar ini sangat di perlukan dalam suatu pembelajaran agar peserta didik dapat menghasilkan sesuatu dalam belajarnya dan juga pesrta didiik ini harus dapat memhami dengan adanya ssuatu respn dan juga dengan hubungan stimulus, maka dari itu respon dan stimulus sangat di perlukan pada masa pandemi seperti ini agar si pendidik dapat menerapkan apa yang sudah pelajari.

\section{DAMPAK DARI SALAH BELAJAR TERHADAP PENCAPAIAN TUJUAN BELAJAR}

Salah belajar terhadap percapaian tujuan belajar ini di pengaruhi oleh dua faktor yang pertama ialah faktor internal dan faktor eksternal, faktor eksternal ini mempengaruhi hasil belajar yang mana jika pelaksanaan belajar baik maka tujuan pembelajaran akan tercapaai, tetapi apabila tujuan belajar tidak baik maka itu tujuan pembelajaran tersebut tidak akan berhasil. Dan kemudian faktor internal juga akan mempengaruhi dari hasil belajjar yang mana faktor internal ini seperti suatu kebiasaan belajar, apabila kebiasaan belajar yang baik akan mendukung terciptanya hasil belajar yang optimal. Dan dampak dari salah belajar ini akan mempenggaruhi hasil belajar dan juga tujuan belajar. 


\section{SIMPULAN}

Teori belajar behaviorisme ialah sesuatu pergantian mental yang ada di dalam orang sehabis melaksanakan belajar, yang mana faktor- faktor terebut tidak di perhatikan serta pula dikira selaku suatu hasil belajar sebab sudah dikira selaku perihal yang tidak bisa diamati serta pula tidak bisa di ukur, serta pula teori belajar ini senantiasa menyyerderhanakan suatu perihal yang mana berkaitan dengan pembelajaran serta ataupun belajar hanya pada sesuatu ikatan stimmulus serta reaksi saja yang mana pula dan sanggup menarangkan penyimpangan yang terjalin dalam sesuatu ikatan stimulus serta reaksi itu sendiri serta teori belajar ini di perluka dalam sesuatu pendidikan terlebih di dikala masa pandemi ini dimana pada dikala ini pendidikan dicoba secara online ataupun dapat di sebut dengan daring, pembuatan relevasi belajar ini sangat di perlukan dalam sesuatu pendidikan supaya partisipan didik bisa menciptakan suatu dalam belajarnya serta pula pesrta didiik ini wajib bisa memhami dengan terdapatnya ssuatu respn serta pula dengan ikatan stimulus, hingga dari itu reaksi serta stimulus sangat di perlukan pada masa pandemi semacam ini supaya sang pendidik bisa mempraktikkan apa yang telah pelajari. Teori belajar behaviorisme ialah sesuatu pergantian mental yang ada di dalam orang sehabis melaksanakan belajar, yang mana faktor- faktor terebut tidak di perhatikan serta pula dikira selaku suatu hasil belajar sebab sudah dikira selaku perihal yang tidak bisa diamati serta pula tidak bisa di ukur, serta pula teori belajar ini senantiasa menyyerderhanakan suatu perihal yang mana berkaitan dengan pembelajaran serta ataupun belajar hanya pada sesuatu ikatan stimmulus serta reaksi saja yang mana pula dan sanggup menarangkan penyimpangan yang terjalin dalam sesuatu ikatan stimulus serta reaksi itu sendiri serta teori belajar ini di perluka dalam sesuatu pendidikan terlebih di dikala masa pandemi ini dimana pada dikala ini pendidikan dicoba secara online ataupun dapat di sebut dengan daring, pembuatan relevasi belajar ini sangat di perlukan dalam sesuatu pendidikan supaya partisipan didik bisa menciptakan suatu dalam belajarnya serta pula pesrta didiik ini wajib bisa memhami dengan terdapatnya ssuatu respn serta pula dengan ikatan stimulus, hingga dari itu reaksi serta stimulus sangat di perlukan pada masa pandemi semacam ini supaya sang pendidik bisa mempraktikkan apa yang telah pelajari. 


\section{DAFTAR PUSTAKA}

Susanto, H. (2020). Profesi Keguruan. Banjarmasin: FKIP Universitas Lambung Mangkurat.

SUARDI.M.(2018). Belajar\& Pembelajaran. Deepublish

Widiaryanti, V. (2009). Perilaku Belajar Ditinjau dari Dukungan Sosial dan Kemandirian Pada

Siswa SLTP Santo Yoseph Denpasar Bali (Doctoral dissertation, Prodi Psikologi Unika Soegijapranata)

Susanto, H., \& Akmal, H. (2018). Efektivitas Penggunaan Aplikasi Pembelajaran Berbasis Mobile Smartphone Sebagai Media Pengenalan Sejarah Lokal Masa Revolusi Fisik Di Kalimantan Selatan Pada Siswa Sekolah Menengah Atas. HISTORIA: Jurnal Program Studi Pendidikan Sejarah, 6(2), 197-206.

Subiyakto, B., \& Abbas, E. W. (2020). Strategi Pembelajaran IPS: Konsep dan Aplikasi.

Rahman, A. M., Mutiani, M., \& Putra, M. A. H. (2019). Pengaruh kompetensi pedagogik dosen terhadap motivasi belajar mahasiswa pendidikan IPS. Jurnal Darussalam: Jurnal Pendidikan, Komunikasi dan Pemikiran Hukum Islam, 10(2), 375-387.

JUMRIANI, J. (2014). PENGELOLAAN KELAS DALAM MENINGKATKAN EFEKTIVITAS PEMBELAJARAN PENDIDIKAN AGAMA ISLAM DI SDN 104 WIWITAN KECAMATAN LAMASI KABUPATEN LUWU (Doctoral dissertation, INSTITUT AGAMA ISLAM NEGERI PALOPO).

Jumriani, J. (2018). KO ASSENG, KO MACCA STRATEGI WAKIL KEPALA SEKOLAH URUSAN KURIKULUM SMK NEGERI 1 WATUNOHU DALAM MENINGKATKAN KEMAMPUAN GURU MENYUSUN PERANGKAT PEMBELAJARAN. Prosiding, 3(1). 